\title{
The Concept of the Village in Swedish Archaeology
}

\section{Jan-Henrik Fallgren}

\begin{abstract}
In this paper the Swedish concept of "by" (village) will be treated. Iron Age settlements will be treated from a historical perspective, the starting point for the discussion being archacological and historical sources from Öland. The notion that single farms were the sole form of settlement during the said period will be seriously called into question.
\end{abstract}

Jan-Henrik Fallgren. Department of Archaeology. Gustavianum. Uppsala University. S-753 lo Uppsala. Sweden.

\section{INTRODUCTION}

Today it is a common notion among scholars of Swedish settlement history that settlement during the Iron Age solely consisted of single farms, and the existence of larger prehistoric settlements has persistently been denied, no matter which part of the country has been studied. The reason this opinion has become established is connected with a debate that took place between archaeologists and human geographers in the sixties and seventies (summarized by Dahlbäck 1977, and later in Broberg 1990:24f). In this paper I will raise objections to this notion from several angles, and call attention to the flaws in the abovementioned debate, referring to the arguments of both archaeologists and human geographers.

As a starting point for and an illustration to my argumentation I will use both archaeological and historical sources from Öland. This source material will also be used to illuminate the similarities and differences between prehistoric and historical villages, thereby revealing the changes in settlement, and also some of the reasons for these changes. Furthermore, the examples from Öland will be compared with prehistoric villages from other parts of Sweden, Scandinavia and continental Europe. I will also compare my material with historical villages of various appearance and content. All in all, one could call this a sort of village morphological comparison in time and space.
As shown by the title the concept of "by" itself will be examined, and I will also make an attempt to establish a more clearcut definition of the Swedish notion of the word. This is important, partly because it was never done during the aforementioned debate, and partly to make it easier to classify remains of buildings in the future, by applying this definition to both prehistoric and historical material. Thus it will be easier to make a classification of settlements of different appearances and traditions dating from the same period.

The most important deficiency in the abovementioned debate is precisely that the concept of "by" was never defined or analysed when discussing single farms versus villages, and the age of the so-called "bybildning" (formation of villages). This can partly clarify the different points of view and also largely explain why there is still today a difficulty in explaining the reason for the so-called "bybildning" or its position in time.

\section{THE SETTLEMENT DEBATE:}

\section{A BRIEF SURVEY}

The difference of opinion between the archaeologists and human geographers who participated in the debate mainly concerned the point in time when the "bybildning" occurred, and the reason for it. Concerning the point in time, it was argued by archaeologists that the "bybildning" had not occurred until during 
the Middle Ages, since the Late Iron Age cemeteries in Mälardalen were generally considered too small to represent buried village populations. This opinion was first presented by Björn Ambrosiani (1964:205ff). This interpretation applied to the eastern part of Mälardalen, but later it came to be largely accepted among students of settlement history in various parts of the country. Ake Hyenstrand, who made quantitative analyses of the registered ancient monuments of Mälardalen, believed that he could confirm the hypothesis of Ambrosiani concerning a settlement structure consisting solely of single farms during the Late Iron Age. He widened the hypothesis so that it came to relate to the entire of Mälardalen and its surrounding areas (Hyenstrand 1974:31f). Strangely enough, the so called "units of origin" from the Early Iron Age there, by the same argumentation, were not considered to have constituted villages.

Earlier the common opinion among Swedish archaeologists and ethnologists had been that the village constituted the original Iron Age form of settlement (e.g. Lindqvist 1935:121; Erixon 1952), which was an assumption not confirmed by empirical studies, Iron Age settlement being largely uninvestigated. When it comes to this part of the country it still is. The notion of single farms being the sole form of settlement spread among scholars, and therefore came to relate to Sweden as a whole.

A few exceptions can be found among those who studied the conditions of the central parts of Sweden (Baudou 1965, JohnsenWelinder \& Welinder 1973), but these works have not had the same impact as the abovementioned opinion. It must here be pointed out that none of these interpretations were based on studies of remains of buildings, only on grave remains.

Human geographers had dated the "bybildning" in Central Sweden to some time between the seventh century and the Viking Age (Helmfrid 1962:168ff; Hannerberg 1977:423 ff; Lindquist 1968:46ff; Sporrong 1971:170ff). The results were based on stud- ies of old maps and fossilized fields, and datings rested on metrological studies and Cl4-tests.

The differences of opinion were just as great concerning the explanation to the "bybildning" and the way it actually took place. Archaeologists claimed that it could only have resulted from the division of farmsteads that took place after the end of the prehistoric period (e.g. Ambrosiani op. cit., Hyenstrand op. cit.). Human geographers, in opposition to this view, claimed that the "bybildning" resulted from an Iron Age converging of separate farms to a common regulated village, this moving together being caused by the introduction of the twofield system (Hannerberg op. cit., Helmfrid op. cit., Lindquist op. cit., Sporrong op. cit.). Agricultural changes were seen by human geographers as the main drive behind changes in settlements, in this case the creation of villages.

The regulated village is a key concept in the discussion below. When speaking about a village, it was a regulated village that was meant, even if this wasn't always clearly stated. Although the concept of "by" was not defined, there was still an image among both archaeologists and human geographers of the "ideal form" of a village. The fact that villages have had different forms was not reflected upon or discussed in the context of prehistoric settlements. This must also be seen as very important to the continued discussion.

A brief summary of these two different points of view:

1.) When material from graves was used as source material scholars claimed that Late Iron Age cemeteries generally were too small to represent a population more numerous than the inhabitants of a single farm. The "bybildning" must then be a result of a division of farmsteads in the beginning of the Middle Ages. There is not sufficient evidence to support this view and it can in large part be discarded as irrelevant.

2.) The arguments of the human geographers concerning the reasons for the "bybildning" 
presupposed that agriculture had a dominant position as the means of livelihood during the Iron Age, and also that agricultural changes automatically led to changes and regroupings of settlements. This cannot be said to be true either. Still, the interpretation that takes the converging as its basis is highly relevant, and it is strongly supported by the source material, while the view of single farms as the only existing form of settlement in the earlier period is highly disputable.

At present the two camps have moved closer in view. Human geographers have given up the earlier datings of the "bybildning", now supporting the view that it took place during the Middle Ages (e.g. Sporrong 1985a:196). And archaeologists have begun to support the idea of a so-called multicentered settlement structure during the Late Iron Age, which is said to have existed before the "bybildning" (e.g. Broberg 1990:24f). All parties still agree that "by" means a regulated village.

\section{THE CONCEPT OF "BY"}

There are several problems connected with the Swedish concept of "by". To begin with, the concept of "by" has a number of different meanings in the Swedish language. Furthermore, a uniform scientific definition of the concept is lacking, although it is most often used as the opposite of "single farm" (Sporrong 1985b). The Swedish language also lacks the distinction between the English "village" and "hamlet", or the German "Dorf" and "Weiler". This terminological distinction contains a quantitative aspect as well as a functional one. "Village" and "Dorf" are units consisting of at least ten separate farms and a church, often also having more functions than the smaller units of "hamlet" and "Weiler" (Widgren, unpublished manuscript).

When the Swedish concept of "by" has been defined, the following criteria have been used: two or more farms should be situated in a limited area of fields, in which all the neighbours have their land separately, in common or in mixed property (Erixon 1960: 195; Sporrong op. cit., Widgren, unpublished manuscript). This definition is close to the definition which is articulated in the oldest cadastral records: two or more farmsteads which go under the same name are said to constitute a "by" (Widgren op. cit.). It is also close to the definition that has been used in Denmark by students of settlement history, the criteria there being that at least three independent farms have existed at the same time, so that they had common rules for their provision (Grøngaard-Jeppesen 1981; Becker 1982:6). Thus, there is both a quantitative and a functional aspect of the concept. Both the number of farms, and forms of cooperation and common interests have formed important criteria.

In the past several scholars have wanted to include a genetic aspect in the concept of "by", in view of the fact that similar groups of settlement not always have the same background. Thus there came to be a difference between what was called "true" and "false" villages. The last category was said to have arisen from the division of farmsteads from an original single farm, while the so-called true villages were said to have their origin in the contemporaneous taking of new land by many people, the land then being divided among a number of farms. This way of reasoning can not be said to be of any greater value, since it is based on a misinterpretation of the origin of the great Continental villages as well as the Swedish villages. Modern research has shown that the medieval villages of any size, that is the regulated geometric villages, have often arisen through joining and concentration (Widgren, unpublished manuscript, see also below concerning the dating of this adjustment). The notion of the falseness of the "false" villages can thus be said to relate to a misunderstanding of the genuineness and the origin of European villages (Widgren op. cit.).

The definitions of the Swedish concept of "by" are as we have seen very similar. There are no real disputes about what is actually meant by "by", neither with regard to the contents nor the function of the word. This 
may seem surprising in view of the aforementioned debate and the difference of opinion among Swedish scientists concerning the so-called "bybildning". It is also remarkable that this definition has never been observed or discussed in connection with prehistoric traces of settlement, but only in connection with the genesis and development of historic remains of settlements. Below I will use the definition discussed above to classify various remains of settlement.

\section{THE SOURCES FROM ÖLAND}

In Öland there is a unique archaeological source material from the Iron Age in the form of about 2,000 preserved house foundations with a complementary system of enclosure walls and fossilized fields. Only in Gotland is there a material as complex as this one. The reason for this is firstly that during a large part of the Iron Age stone was used for walls and fences on both of these islands. On the Swedish mainland however, houses had wattle and daub walls during this period, while in some parts of the Swedish mainland there are fossil remains of stone fences.

The type of house in Öland was the socalled three-aisled house, which was common in northern Europe and which had inner roofsupporting posts. Only a few house foundations have been examined here, which means that the time-span during which they were constructed is not fully elucidated. It has been made clear, however, that this type of house existed in the fourth century and that it continued to do so until sometime during the eighth century (see Fallgren 1988:15f, and the literature mentioned in this work). These fossil remains of settlements from Öland have principally been interpreted as the remains of single farms (see summary in Fallgren op. cit.: $49 \mathrm{ff}$ ).

In northern Öland, in the parish of Böda, there are the most well-preserved Iron Age remains of settlements. The main reason for this is that this part of the island has been part of the royal hunting ground since the eight- teenth century. This area, then, was protected from the destruction by cultivation that had taken place in other parts of the island, when the so-called royal common was divided among the villages of Öland after 1810 (see Fallgren op. cit.:13f).

The starting point for the following discussion concerning Iron Age village-settlements is taken from this part of Öland. These two villages are representatives of two of the three different size categories of villages (fig. 1 and 2). The villages of Öland can normally be classified into one of the three categories. Rosendal, fig. 1, belongs to the middle-sized villages, while the settlement of Skäftekärr, fig. 2 and 6 , is a representative of the large villages of Öland. The author of this article has for the past few years pursued archaeological excavations of both these villages.

In Rosendal, which is the most well-preserved Iron Age village of Öland, there are fourteen house foundations and a very extensive and well-preserved system of enclosure walls. The infield lands are enclosed by it, and the enclosures also form cattle roads in several places. These enclosures, consisting of stone walls, are in some places single-row walls, and in others they are powerful dry stone walls. The latter are still standing, and in some places they reach as high as 1.5-1.7 meters above ground. The fourteen house foundations correspond to 5-7 farms (see Fallgren op. cit. 3 lff). The fossilized fields which at present are detectable are mainly grouped close to each farm. Each farm seems, in view of the preserved enclosures, to have a gärde where the meadows and fields are situated. Only one large farm, facing south, has apparently had two or three gärden.

In three directions the area is surrounded by the graves of the village. The largest cemetery is situated in the west, on a boulder ridge. Another cemetery lies closer to the buildings in the south-west, and two stone-settings lie on a hillock in the east. The latter two are probably what are now the only visible parts of a single large cemetery. The village is bordered by large, now drained, fens in the 


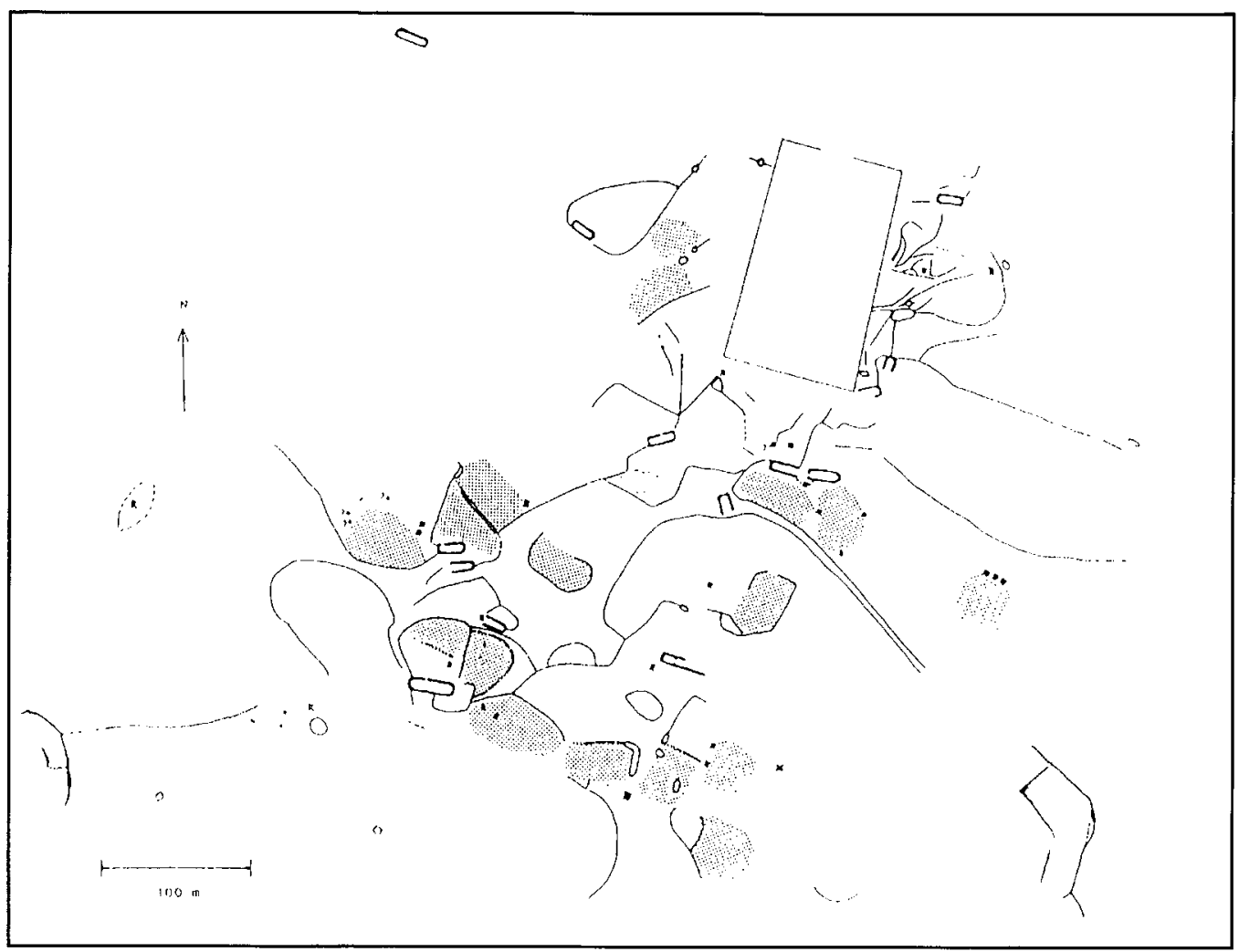

Fig. I. The iron-age village in Rosendal. Böda parish. Öland. Hatched areas shown arable fields. Map from Fallgren 1988 with supplements.

north and south. The area is thus very well defined, both concerning the terrain and concerning other settlements. The largest part of the village is situated in a coniferous woods, and is untouched, except for the northern part, where the house of a forester was built in the beginning of this century.

The Iron Age settlement of Skäftekärr, on the other hand, is partly situated in presentday agrarian landscape and has therefore been seriously damaged by cultivation. In spite of this there is a remarkably large part of the old settlement left.

In Skäftekärr there are a total of 20 or 21 house foundations, see fig. 6.12 or 13 of these are placed on the side of a central cattle road, which in several places extends into the common. The fossilized fields are for obvious reasons not so many here, although there are a few. In the central part the farms are larger than the farms of Rosendal, see fig. 2, and the number of gärden for each farm seems to be two or more. There is a large cemetery to the north-west of the central part of the village. In the north-east there is a large stone cairn and possibly a couple of small stonesettings. Earlier it has been difficult to connect the large cemetery to this settlement, mainly because of the distance and the lack of an obvious spatial connection. Now that several more house foundations have been discovered, the spatial connection is confirmed. The number of farms has been estimated to between 10 and 12. The two house foundations farthest to the south are now destroyed by cultivation, but they are registered and marked on old cadastral maps. The village and the area as a whole are bordered by two large fens in the southeast and several small fens in the south, which in present time have been drained. 


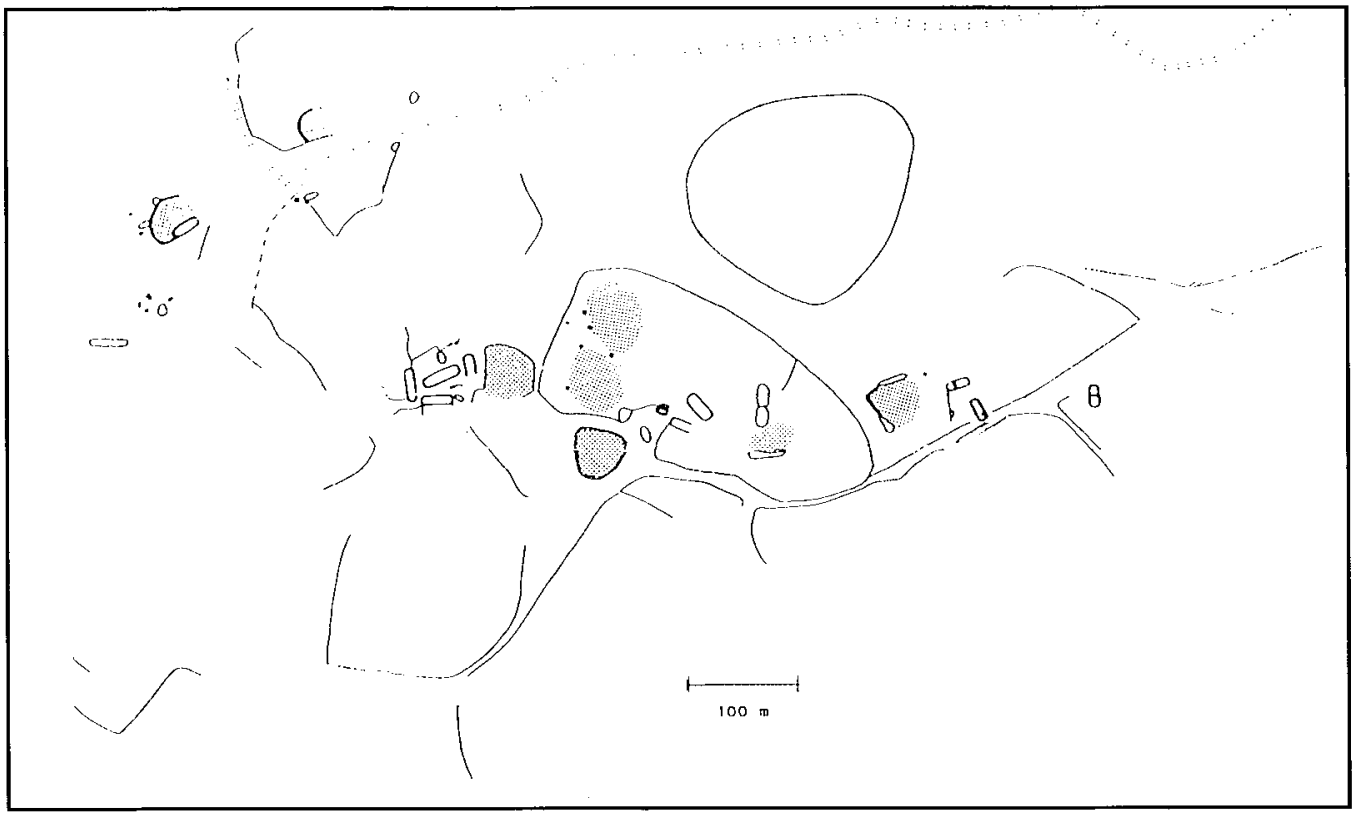

Fig. 2. The iron-age village in Skäftekärr, Böda parish, Öland. Hatched areas shows arable fields. Map from Fallgren 1988 with some new supplements.

\section{The structure of settlements}

It is clear that these two groups of buildings represent village settlements. The afore-mentioned definition of "by" makes it easy to classify both of these settlements as "byar" (villages). Both of them fulfill the quantitive as well as the functional aspect completely. The number of farms in both settlements is well above the required minimum of two. In both settlements there are also well-defined areas of infield, where the farms seem to have owned their land separately. The functional aspects are fulfilled mainly through the common cattle roads, and possibly through the burial-grounds. It is of course possible to raise objections to the claim that the farms are contemporaneous, since only one farm in each village has as yet been excavated. However, there is nothing in the structure of these villages that contradicts the claim that all the registered houses existed contemporaneously. On the contrary, the house foundations, the enclosures and cattle roads have an apparent functional connection. The pattern made by these different components is very important in this context, as it always is when one discusses villages. This pattern is not unique for these villages, but is a common feature of all fossil Iron Age settlements in Öland, although there are regional variations.

The most important features, which are found everywhere on this island, are as follows:

1.) Buildings are always centrally placed in the infield lands.

2.) Cattle roads, most often shared, connect the different farms with the common lands and with each other.

3.) Stone walls surround irregularly shaped enclosures of similar size.

4.) One, two or sometimes several large gärden are placed in direct connection with the farm, so that they sometimes form a pattern similar to the rings of a tree.

5.) The arable land is mainly concentrated close to the farm buildings.

6.) One farm is always larger than the other farms in the village. 
7.) The cemeteries are usually situated where the infield lands end and the common lands start. There are often two and sometimes three cemeteries, which are placed in the direction of the nearest neighbouring villages.

Almost all Iron Age house foundations in Öland are thus grouped in these scattered, irregularly formed, small, middle-sized or very large villages. Unlike in Gotland it is very hard to find or to discern single farms among the remaining house foundations (see Fallgren 1988:51). The most important reasons for not having earlier considered the Iron Age settlements in Öland to be villages are partly that entire house-foundation blocks have not earlier been mapped, only single scattered farmsteads (e.g. Stenberger 1933), and partly that the scholars who compare prehistoric settlements with historical ones have taken the structure of the row-villages as their starting point.

However, what can be called the last and perhaps the most important confirmation of the hypothesis that these groupings of buildings on Öland really represent village settlements, is that their main features are almost identical to the historical non-regulated villages of northern Öland, as they are shown on the oldest maps. The characteristic feature of these villages is that they often lack any form of geometric pattern, whether concerning the shape of farms or the shape of infields/gärden. Almost all the above-mentioned characteristic traits of the Iron Age settlements in Öland, can also be used to describe the historical villages of northern Öland, which have a totally different structure than the very strictly geometrically-formed regulated villages of southern and central Öland.

\section{COMPARISONS WITH OTHER IRON AGE VILLAGES}

When comparing the examples from Öland with other comparable Iron Age villages in Scandinavia and on the Continent, well-known from the archaeological literature, several interesting and enlightening differences emerge.
These differences can in many ways shed light on differences in the Iron Age morphology of villages. What most clearly emerges are above all the differences in the structure of the villages, and the enormous areas covered by settlements in Öland. This is caused by the very irregular shape of the villages of Öland. Danish and Continental villages have, on the other hand, a more or less regular shape, and the settlements are therefore much denser. What is also typical of the villages of Öland is the total lack of toft-like structures or limitations, which are often found in Denmark and on the Continent. This is also the greatest difference between these villages and Vallhagar, which is certainly not a typical representative of the contemporaneous settlements of Gotland, but neither is it an exception, since several Gotlandic Iron Age villages actually have these limitations (see Nihlèn \& Boethius 1933: fig. 4 and 7). With these the Iron Age settlements of Gotland have more in common with, for example, the villages of Jutland than with those of Öland! See fig. 3, left and right side. The morphological differences between the examples from Öland and the rest will be treated later in this paper. The lack of enclosed tofts is also something typical of the unregulated historical villages in Sweden, see below.

The examples from Denmark, Germany, and the Netherlands given in fig. 3 have been included in the comparison partly to illustrate the contrasts in Iron Age morphology, and partly because they constitute some of the most extensive excavations of Iron Age settlements in northern Europe, when it comes to the sheer size of the areas examined. Thus they constitute a relevant source for comparison with the villages of Öland. But it must be pointed out that there are also small, less regular and more scattered villages in continental Europe and in Denmark, for example in Odoorn, Drenthe, in the Netherlands during the fifth to the eighth century (see Schmid 1986:239, fig 85) in Österbölle from early Roman time, and in Sejlflod in Jutland (see Hvass 1988: fig. 6 and 29). 

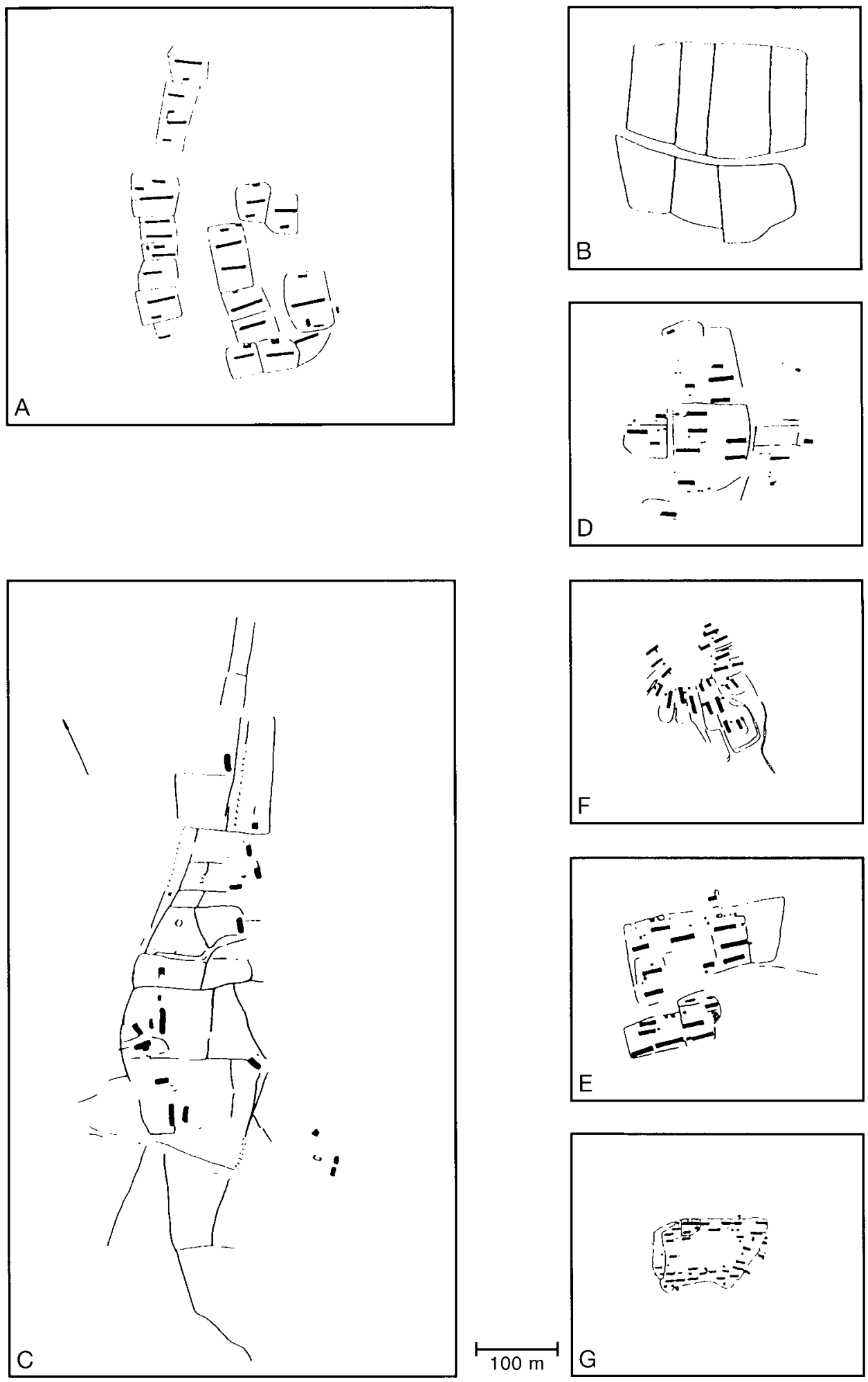

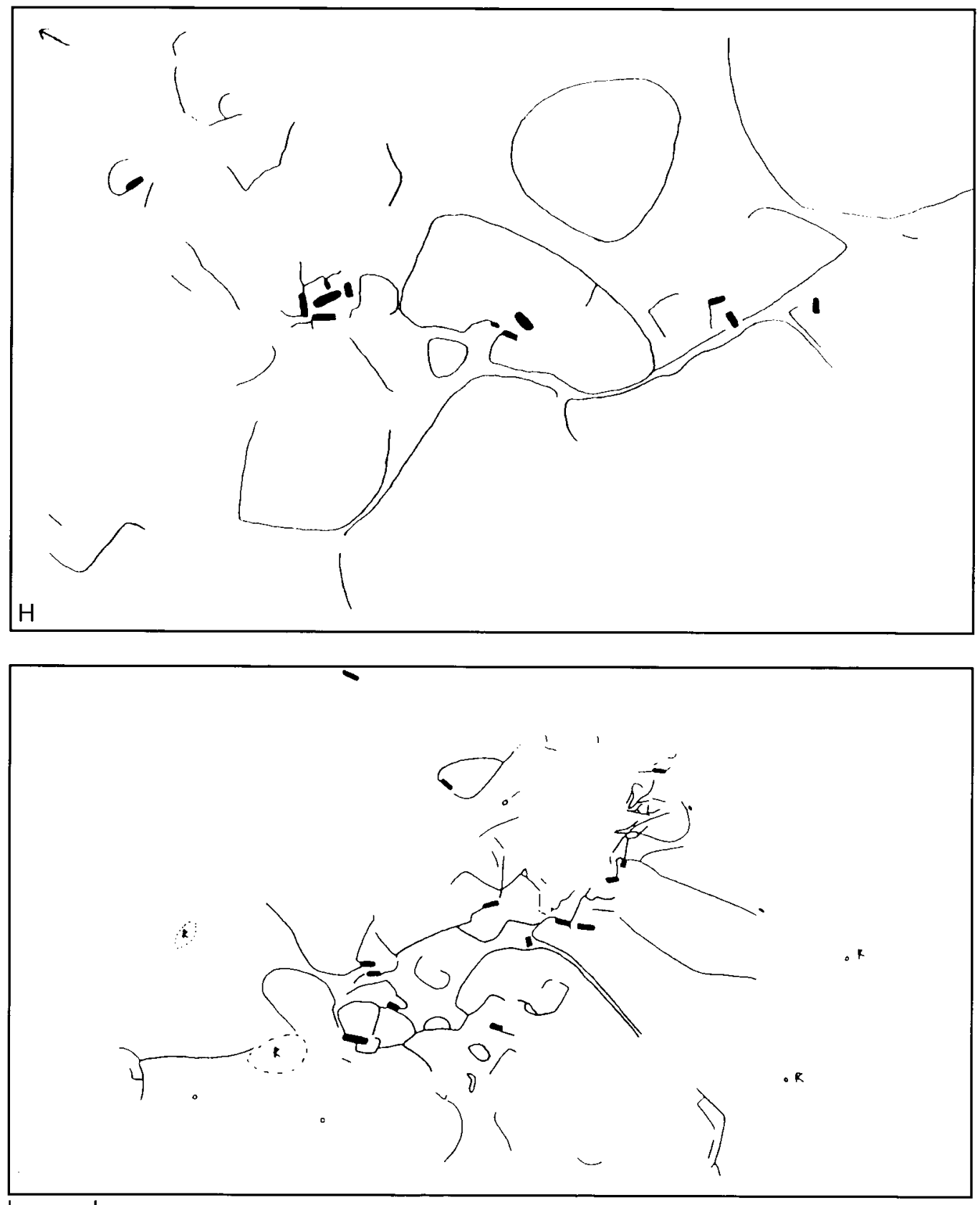

$100 \mathrm{~m}$

Fig. 3. Iron-age villages: A. Vorbasse, Jutland, Denmark in the 4th century A. D. (after. S. Hvass 1988). B. Vorbasse in the 8th-10th century A. D. The tofts of the farmsteads (after S. Hvass 1988), C. Vallhagar, Golland. in c. the 3rd-7th century A. D. (after M. Stenberger 1955), D. Wijster Drenthe. Netherlands, in the 4th century A. D. (after P. Schmid 1986), E. Flogeln, Germany, in the 2 nd-3rd century A. D. (after P. Schmid 1986), F. Feddersen Wierde. Germany, in the I st-2nd century A. D. (after P. Schnid 1986), G. Hodde, Jutland, Denmark, around the Birlh of Christ (after S. Hvass 1988). H. Skäftekärr. the central part. Böda parish, Öland. in c. the 4th-8th century A.D. (after Fallgren 1988), I. Rosendal, Böda Parish, Oland, in c. the 4th-8th century A. D. (after Fallgren 1988 ). 
The preserved system of enclosure walls in the villages of Gotland and Öland is another remarkable difference between the Continental and Danish villages and the villages of Oland and Gotland. It is also the greatest advantage of the source materials of Gotland and Öland in relation to the Continental and Danish source materials. In Öland and Gotland it is thus possible to reconstruct the whole area of Iron Age infields. To a large extent this is also true for certain parts of the Iron Age settlements on the Swedish mainland, above all in Östergötland (see Lindquist 1968; Widgren 1983).

Thus there were great morphological and structural differences between different Iron Age villages of northern Europe. It is, howev- er, more difficult to determine whether there were also great differences concerning modes of cooperation, the use of the land and its ownershipsystem etc. However, on the basis of our knowledge about morphologically different villages in the historical period, the differences being in many ways the result of different historical situations as well as differences in the cultivation and division of land, some fairly good parallels can be made, see below.

\section{COMPARISONS WITH THE HISTORICAL SETTLEMENTS}

The fact that there were great differences between the villages of historical time is as

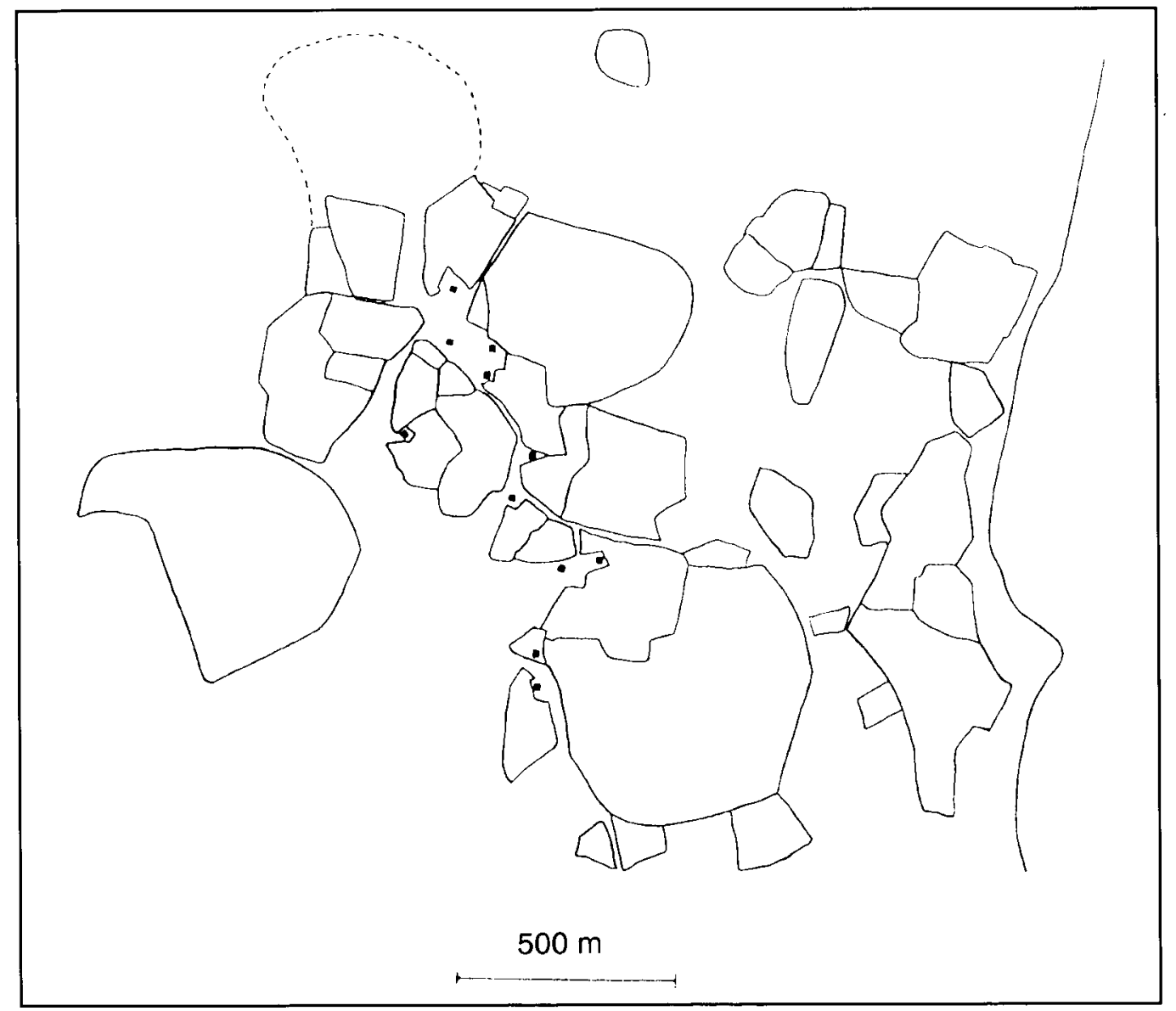

Fig. 4. The village of Dödevi, Högby parish, Öland. Drann from a map from 1736. 


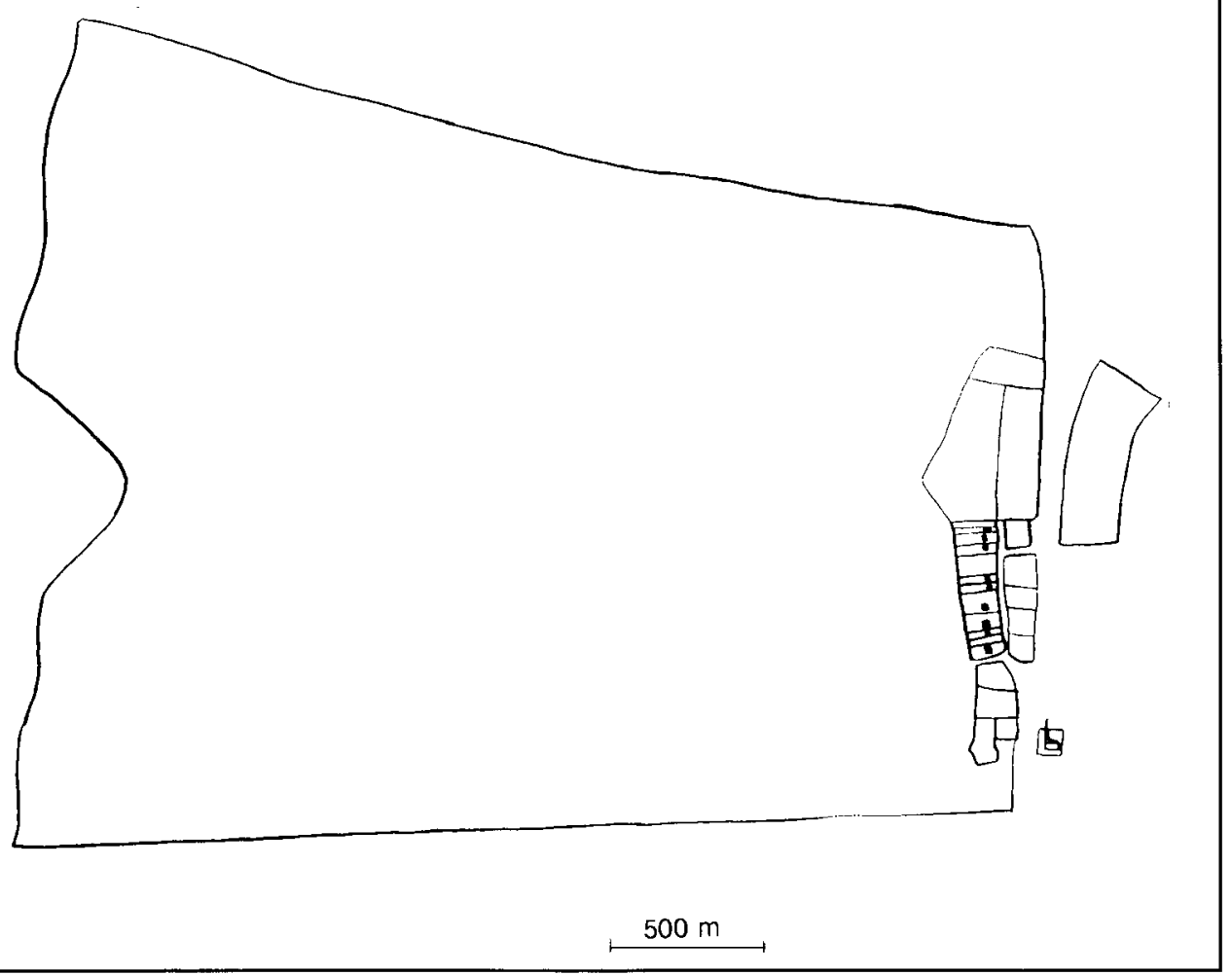

Fig. 5. The village of St. Vickleby, Vickleby parish. Öland. Drawn from a map from 1641.

obvious as for those of the earlier periods. It has, however, very seldom or never been noted in relation to discussions about Iron Age settlement patterns. Instead, in the cases when comparisons have been made, the old remains have always been compared with regulated villages. The material for comparison has thus constituted an ideal type or picture of how medieval and historical villages looked. But these villages can not be said to be representative of the settlements of historical time or of the whole country, since they are mainly concentrated to the eastern parts of Sweden (Erixon 1960; Göransson 1986:37). If we go back to Öland, we see further that in a limited part of Sweden like Öland there were enormous differences in form and principle concerning the shape of the villages: on the one hand the villages of northern Öland, and on the other hand those of southern and central Öland, see fig. 4-5.
To enable a comparision between the prehistoric and historical villages of Öland, I have only drawn the enclosures that are registered on older maps, together with the farms, on the maps of fig. 4 and 5. Consequently I have not drawn any other possible boundaries, e.g. between different strips of land, or other limits of land, but only the boundaries that have been marked by fences. In this way one gets a relevant historical source of comparison, which can be compared to fossil Iron Age settlements. In fact, it is precisely the enclosures (except for the house foundations) that remain of Iron Age villages in the fossil remnants. My point is this: that a comparison between settlements of different periods should be made between the same type of phenomenon. If not, it is bound to turn out irrelevant.

Village boundaries of late historical settlements have often been compared with the stone walls of fossil settlement remains. This 
procedure has given rise to the opinion that Iron Age settlements often correspond poorly with historically known villages, and that agrarian landscapes of different periods have no connection (e.g. Widgren 1983:101ff; Sporrong 1985a:193f). The discordance between prehistoric infield boundaries and historical village boundaries is of course many times very real. However, to compare the infield boundaries of the Iron Age with village boundaries of later periods is to make a comparison between totally different phenomena. Permanent boundaries between different villages can only have been made when common land was divided, and the boundaries of the outlying land were settled. Since the boundary marks could consist for example of a boulder or a big tree, the prehistoric boundaries are naturally impossible to identify and register. There simply is no prehistoric source material corresponding to the source material of historical village boundaries.

Dan Carlsson, on the other hand, has compared Iron Age infields with those of historical villages on Gotland, and he points to a remarkable similarity between the agrarian landscapes of different periods (1979: fig. 118). These results are also valid for Öland, especially the northern part (Fallgren 1988:45ff).

\section{The historical settlement in Öland}

When comparing Iron Age villages with the well-known historical regulated row-villages of Öland, differences are easily discovered. See fig. 5. In earlier comparisons between Iron Age and historical settlements in Öland, as well as in other parts of the country, the above-mentioned type of historical settlement has been the sole representative of historical villages (see Fallgren 1988:52ff, and literature mentioned in this work).

The row-villages of southern and central Öland, the origin, contents, and development of which has been analysed by the human geographer Sölve Göransson, are characterized by geometry and regularity, the lots of the villages being arranged in cohesive geometric figures. In accordance with the existing enskifte every village usually had just one, regularly formed gärde, fields and meadows not being separately enclosed. This is typical for what in agrarian studies is called the openfield system, which is seen as typical for European medieval villages. Furthermore, the buildings were most often situated on the border between infields and common, so that cattle could easily be let out to pasture (Göransson 1969:70). An example from St. Vickleby 1641 (fig 5) shows that the nine farmsteads of the village lie in a row in the easten parts of the infields. The "gärde" was shaped like a single enormous regular square, $80 \%$ of which consisted of meadows.

The contrast with the described village structure during the Iron Age is great. The only thing in common is that the arable land, which has not been marked on the maps, was still very small compared to the meadowground of the seventeenth century, and also that intensive stock-raising has been practised together with intensive agriculture (compare to Fallgren 1988:61 ff). Turning to northern Öland, where the majority of villages have not gone through the radical medieval reshaping of settlement structure, the contrast mentioned above is not as striking. Furthermore, the differences between the two contemporaneous settlements are just as great as between the Iron Age settlements of Rosendal and Vorbasse.

Fig 4 shows Dödevi by in the parish of Högby. This village consisted of 11 farms in 1736. The farms were scattered, and lay mainly along an extensive cattle road, that branched out in several different directions. Unlike the village discussed above, Dödevi had a large number of "gärden", irregular in shape. Buildings and infields totally lack the regular geometry and concentration that is so characteristic for regulated row-villages in southern Öland. The entire settlement structure as described here has a lot in common with the afore mentioned Iron Age settlements. The grouping of and the distance between the 


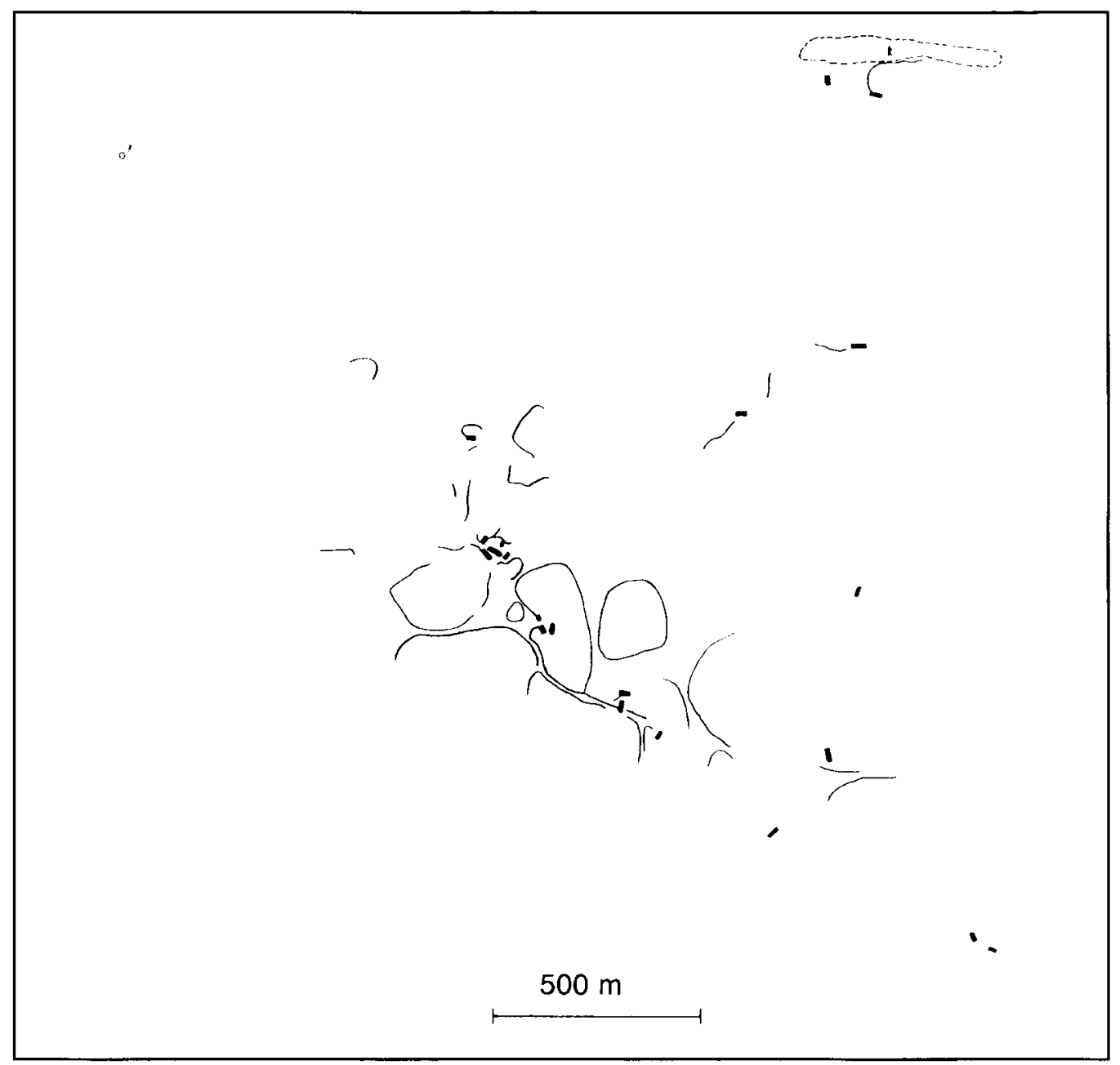

Fig. 6. The iron-age village in Skäftekärr. Böda parish. Öland. The total settlement.

farms, along with the distance between the northernmost and southernmost farms of Dödevi, are almost exact equivalents of the conditions of the Iron Age village of Skäftekärr. The calculated number of farms in Skäftekärr is also the same as that of Dödevi, see fig. 6.

Sölve Göransson has earlier pointed out that the appearance of these unregulated villages probably gives a clue as to how the villages of southern and central Öland looked before the shaping of the geometrical "gärden" and the regulation of settlements (1969:76). Almost all of the features that were described above as characteristic of the pattern of Iron
Age settlements in Öland, can also be said to be characteristic of historical villages of the northern part of the island. The one feature that is not valid is of course the one concerning the cemeteries.

\section{Unregulated villages in Sweden}

The type of historical village represented by Dödevi is not unique in Sweden. Villages with similar groupings of farms and irregularly shaped infields have existed in most provinces. Furthermore, in both early and late periods many villages in Sweden lacked the 
inner concentration of farms and the mixture of landed property of infields, which are usually included in the concept of "by".

The ethnologist Sigurd Erixon, who made extensive examinations of this type of village (1960), divided the villages into two main categories:

\section{1.) disjointed enclosed villages}

\section{2.) unregulated villages with open farm prop- erties.}

The latter developed out of the first category; the system of disjointed enclosures has been shown to be primary in relation to open "gärden" held in common (op. cit.:212). The disjointed enclosed villages were divided into three groups by Erixon, which were called "fogbyar", "mötbyar", and "strandradbyar" (op. cit.: 199). The so-called "fogbyar" and to a certain degree the "mötbyar", are the most interesting ones in this context, since they are in many ways similar to prehistoric villages and unregulated villages of Öland. The buildings of the "fogbyar" were normally widely scattered and divided into a number of groups of farms; the farms were linked to each other in a continuous conglomeration of enclosures. There were no regularly shaped or enclosed lots, but the farms were placed on what Erixon called "farm properties". These farm properties were groups of infields including, except for the farm itself, a few fields, often the best fields of the farm, as well as a few other plantations and meadows. Sometimes the farm properties included the entire area of infields of a particular farm, which was the case in Härjedalen and Jämtland. More likely, however, they were supplemented by further enclosure and private groups of infields, which were types called "bitäkter" by Erixon. These two formed the so-called "home-properties" of a farm. Furthermore, it was characteristic that no mixture of property existed, or only a very limited one. The common was, however, shared property (op. cit.:200f, 229f).

The above-mentioned features of these "fogbyar" are very similar to those of the Iron
Age villages of Öland, and those of the irregular villages of the northern part of the island. The description also fits very well to the other known fossil Iron Age remains of settlements in Sweden, for example in Östergötland and in Gotland. Sigurd Erixon, not having access to this extensive source material, assumed that the structure of the disjointed enclosed villages probably was founded on prehistoric traditions (op. cit.:206).

\section{The distribution and change of the infields}

There are several differences concerning the cultivated land in the historical settlements of Öland. The cultivated land of St. Vickleby was mainly situated within geometrical blocks north and south of the farmsteads, and in the separate infield area to the east of the buildings. There were also small lots of arable land in the great "gärde" west of the farmsteads. The cultivated land of the regular villages was farmed in a form of regular field system, the so-called sun division, and was divided into different units of arable land, each farm in the village having its landed property divided into different strips of land, so that all of the farms in the village got their share of land of different quality (Göransson 1985a:7lf; 1986:40). The system was thus one of complete mixture of landed property.

In Dödevi however, the cultivated land and the rest of the infields were more concentrated to the immediate surroundings of each farm, similar to the way in which Erixon described the conditions of the typical "fogbyar". The main part of the fields and meadows thus corresponded to a so-called "tomttäkt" with so called "bitäkter". Moreover, there were a few large separate infields in the easternmost area close by the sea, which together constituted the largest area of cultivated land of the village. The mixture of landed property was also more thoroughly accomplished here. It is also noticeable in the other "gärden", though not as evident as it is in the regulated villages. A lack or only a very limited mixture 
of landed property was also a very characteristic feature of the so-called "fog-byar".

The expansion of fields and meadow-ground which was characteristic of a village like Dödevi and the villages described by Erixon (1960:247) mainly took the form of individually taken closes ("intagor") in the common. The gaps between all the different "gärden" on the map of fig. 4 were eventually filled with new intakes. The latest map shows an almost entirely continuous area of infields from the sea-shore to the western border of the village. In accordance with the unregulated villages in other parts of Sweden, as described by Erixon, more peripheral and later intakes, which here usually came into existence through joint activities on the common lands, exhibit a more regular strip division than the others, and the mixture of landed property was therefore more thoroughly affected here (op. cit.:235). This was accordingly also the case with the eastern "gärden" of Dödevi.

The expansion of the infields in these villages forms a pattern of irregularly shaped, large and small, enclosed intakes from the centre, or rather several centres, and outwards (cf. Erixon op. cit.:201). Through this the extension and direction of the cattle roads could change over time. This is also characteristic and valid for the Iron Age villages of Öland, where the extension of the infields and the number of farms within the villages almost always give the impression that the villages here expanded gradually, from one or more centres. The farmsteads situated farthest from the centre are usually the smallest ones, for example. It is also not unusual to find cattle roads that have been cut off by more recent enclosures in the villages of Öland. There is thus a great number of structural and morphological similarities between the Iron Age villages and the historical unregulated villages of Öland and elsewhere.

These observations are in line with, and confirm, the new results of Dan Carlsson and his revised opinions concerning the causes of and method for introducing the two-field system in Gotland (1986a:35). Earlier he and many others claimed that the two-field system was introduced during a very limited period of time, which then should have implied that the infields doubled and that a reshapening of the entire agricultural landscape took place (1979:146). Also, the so-called "bybildning" (forming of villages) has been connected to the introduction of a two-field system. Carlsson's recent field-studies, together with studies of the quality of fields in old cadestral records, has on the contrary shown that the area of the fields continually and gradually expanded, which among other things meant that meadow-grounds diminished. Consequently the cattle stock diminished and therewith also the supply of manure. In the long run it meant that a larger share of the fields must regularly lay fallow. In this way the necessary conditions for a regular system of fallows, the two-field system, was created (1986a: ibid.; 1986b:89ff). Sigurd Erixon had earlier put forward a similar line of thought (1960:214).

The introduction of the two-field system should thus not be seen as a stage in an evolution, whereby the introduction of a regular system of fallows meant a transition to a more highly developed stage. Rather, it should be seen as a sign of crisis in the agrarian balance between fields and meadows, agriculture and stock-raising.

\section{FORMS OF COOPERATION AND OWNERSHIP DURING HISTORICAL TIME AND THE IRON AGE}

Certain differences concerning individual and collective work input existed between villages with open-field system and the enclosed villages, which were partly discussed above.

Field cultivation in historical time was always carried out separately by each farm, both in regulated and unregulated villages (Erixon 1960:209). Harvesting, however, could involve the participation of neighbours. Closing and opening gates in the fences was a matter of cooperation between neighbours in the villages which had common enclosures, that is, open fields. 
Within those villages which had a regulated field system during the period from the Middle Ages to the enclosure movements of the eighteenth and nineteenth centuries, there were several rules and collective decisions which each farmer had to accept and follow. It could be a matter of organized cooperation concerning the opening and closing of communal gates, temporary or permanent work teams during harvest time, and participation in hay-making, which often was an object of organized cooperation (Erixon op. cit.; Sporrong 1985a:57, 81; Sporrong \& Widgren 1986:5).

These rules and decisions meant that the inhabitants of a village submitted to a certain degree of compulsion, which also naturally rendered support, but consistuted an impediment for individual initiatives and personal freedom of movement (Erixon op. cit.). English scholars studying the agrarian landscape have claimed that the genesis and significance of the regular field system were mainly socially conditioned, the division of the infields functioning as a hindrance to leaving the system, thereby forcing the peasants to cooperate (Dodgshon 1980:47ff, 74).

The unregulated or disjointed enclosed villages, with their mainly individually and separately concentrated infields in connection with the separate and scattered farms, naturally involved a weaker organization and less need for cooperation than the situation in the afore-mentioned villages. Still, the constructing of cattle roads and the care of village streets demanded cooperation and agreement, which is also emphasized in the medieval provincial laws. It was above all cattle roads and village streets, together with the enclosures themselves, that constituted the most closely uniting elements of the villages. The use of commons was of course also a joint matter. In comparison with the regulated villages, however, a more individual sort of farming was pursued, each farm being to a lesser extent dependent on collective rules and decisions (Erixon 1960:227f).

Concerning Iron Age forms of ownership and cooperation, it has been common for scholars to assume an evolutionist development, collective rights in land being considered primary in relation to individual rights in land. It was also assumed that the large European regular villages, with their common open infields, and the village community itself, were the last remains of a system of collective ownership and cultivation of the land, the village being an economic unit (see Erixon op. cit.:209; Sporrong \& Widgren 1986:3ff; Widgren 1986:21, and other works mentioned in these books). Earlier opinions concerning Iron Age kinship relations have also contributed to these ideas, together with opinions about the land-ownership rights of the old kinship-based society (see Widgren op. cit.:18ff). More recent research has instead shown, as has been pointed out earlier regarding the regulated villages, that both the inner organization and the placing and formation of the buildings were products of the Middle Ages (Widgren op. cit.; Göransson 1980).

Contemporaneous archaeological sourcematerial has without exception shown that the greater part of the farms, during almost the entire Iron Age, represent units of cultivation of a size large enough for a nuclear family (e.g. Carlsson 1979:154; Myhre 1983; Widgren 1986; Edgren \& Herschend 1982:16ff). Also, house foundations and farms that have been studied almost always point towards livestock kept individually by each farm (e.g. Myrdal 1984:80; Fallgren 1988:27, 41ff). Where boundaries of infields and fossilized fields remain, they are placed in the same way as has been earlier described when discussing the infields of Iron Age settlements in Öland. This mainly means separate areas of fields and meadows belonging to each farm, something that is also true for other parts of the country that have fossil Iron Age agrarian landscapes (see Carlsson op. cit.; Hatt 1939; Widgren op. cit.). From what is apparent from the archaeological sources, Iron Age farmers seem to have carried out their farming separately.

When it comes to the contemporaneous 
conditions in continental Europe, there are also historical sources that are able to shed light on these questions. The Frankish law of the eighth century, Lex Salica, contains several items of information about them. A couple of different types of agricultural organization are mentioned, but the most important agricultural unit, or farm, to be treated by the law is the separate and independent allodium run by the free Frankish family together with its slaves and other people in dependent positions. The information that the law contains concerning family size and composition shows that the Frankish families usually consisted of husband, wife, younger sons, unmarried daughters and other dependents including serfs and slaves (Fisher Drew 1991:39, 49). This information is comparable to obtainable items of information in the Icelandic Sagas with regard to the composition of farm populations. The nuclear family is the base which is supplemented by different sets of free servants, serfs and slaves (see for example Njal's Saga and Egil Skallagrimsson's Saga). Tacitus also mentions farm-work as being mainly run by the slaves of the farm (Tacitus Germania, vol. I, 1974:60f).

Aron Gurevitj, who has studied and compared the character of the Frankish allodium with the English and Scandinavian counterparts of "folkland" and "odal" found several similarities between them. This is especially true concerning conditions of ownership and cultivation. All three types of land were, according to customary law, owned and used by three-generation families, and not even during the Middle Ages was it possible to sell these properties. However, through the gradual change of the allodium, caused by the peasants' increasing feudal dependence, the collective control over the use of the allodium became stronger and stronger (op. cit.:48).

Contemporaneous source material does not, then, point to collective forms of cultivation as being dominant in this period. On the contrary, it shows that separate cultivation of farms by small units was usual. However, there also existed various forms of collective labour input of varying importance in these villages.

Collective and individual features can thus not be said to be of different age and origin when discussing the period treated above, which has recently been pointed out by human geographers as well. The specific sets of individual and collective rights of disposition should in every case be treated as functional wholes, and not as evolutional phases: the collective features being considered the original ones (Sporrong \& Widgren 1986).

Concerning the comparison between Iron Age and historical unregulated villages it can be stated as a conclusion that there must also have existed functional similarities, that is, similarities in cultivation and cooperation other than the morphological and quantitative ones hitherto displayed. The development of dispositional rights and ownership rights during the Iron Age was from separately-farmed, non-disposable land to collectively cultivated, eventually privately owned and thereby fully disposable land.

\section{HISTORICAL SOURCES OF SETTLEMENT STRUCTURE}

When it comes to written evidence of the existence of villages it is naturally difficult to find such evidence regarding Sweden during the Iron Age. However, there is some evidence on runic stones dating from the last phase of prehistoric time. For example, it is stated on a runic stone from Lerkaka in the parish of Runsten in Öland, that the rich man Unn owned half of the "by" (Söderberg \& Brate 1906:101f). There is, however, more written evidence concerning continental Europe, such as when Tacitus describes the Germanic villages of the first century as groups of scattered farms (Tacitus Germania vol. I), or the mentioning of villages in the earliest Germanic laws, e.g. Lex Salica (Fischer Drew 1991:49).

The medieval Swedish provincial laws can serve as a source of information about the Swedish conditions. For our purpose the most 
interesting parts of the laws are the decisions regarding regulation of settlements in accordance with the sun division, which are found in the so-called "byggningabalk", "byalagsbalk" and "jordabalk" (different sections of the laws). These laws assume the existence of villages and refer to villages with a different and older structure! Above all it is phrases like "om bönderna vill bygga en by på nytt eller om den ligger i hammarskifte och fornt skifte" (about how a village should proceed with the "skifte") (UL, B I; VmL, B I; Holmbäck \& Wessén 1933; 1936), and "Nu vilja bönder bygga en by; då skall man nedsätta och med ed stadfästa råmärken omkring den by, som de vilja bygga..." (relating to the founding of the village where it was legal to do so. In this case "bygga" actually means "rebuild") (ÖgL, B I; Holmbäck \& Wessén 1933). These phrases imply that the geometric design of the villages took already existing villages as a starting point, and that villages have earlier had a different structure. Just as interesting and important are the expressions about villages found in the laws of the southern provinces: "byggd och gamal, by med högar från heden tid" (ÖgL, B XXVIII), "...högaby och från heden tid byggd" ... "denna by har varit full by både i heden och kristen tid" (VgL I; VgL II; Holmbäck \& Wessén, 1946). These phrases are clear evidence that village settlements existed in prehistoric times in these provinces.

However, the provincial laws give no information about how the villages were structured before the regulation of building lots, or what was meant by "hammarskifte" and "fornt skifte". Still, the important thing is that "hammarskifte" and "fornt skifte" were seen as opposites of the state of regularity and geometry implied by "laga läget", "rätt skifte" (legally arranged lots) or "solskifte" (sun division). Regulation at that time being a novelty, earlier settlements and infields must then have had an irregular and scattered form (cf. Hombäck \& Wessén 1933:187, n. 2), which means that they were villages of the type treated above, that is unregulated or disjointed en- closed villages. Their originality in relation to the regulated villages and open-field villages has been stated above.

With regard to the dating of the regulation of settlements, as it is described in the medieval provincial laws, geographers have earlier dated it to the Viking Age or to the beginning of the Middle Ages (Hannerberg 1977:425), or even to the seventh century (Lindquist 1968:49; Sporrong 1971:170ff). However, decisions regarding the regulation of building lots can on the other hand be shown to have been added to the laws when they were rewritten and modified in the late thirteenth century, the language being of a later period than that of the main part of the law. Taking this into consideration, the regulation could not have occurred until sometime during the fourteenth century at the earliest (Göransson 1980:82).

Since the regulation occurred according to the prescriptions of law, villages gained a more steady and regular appearance "ett laga läge" which probably implied that these villages became less prone than earlier to move from one part of the village land to another.

\section{REGULAR FORMING OF THE SETTLEMENTS}

We have already seen that there were early regular settlements, fig. 3. But that these prehistoric villages wholly correspond to what is meant by "laga läge" in a medieval regular village, as suggested by Sten Hvass (1988:89), is not necessarily true, in spite of the fact that their boundaries are often very similar to the boundaries between building lots. However, Vorbasse had without doubt features - during the Late Iron Age and the early Viking Age which strongly remind us of the historically known building lots that are known from the oldest maps. The feature that I mainly have in mind is the much larger and even more thoroughly geometrically shaped boundaries between building lots, see fig. 3B. Not even these necessarily had the same function and purpose as those of the large medieval villag- 


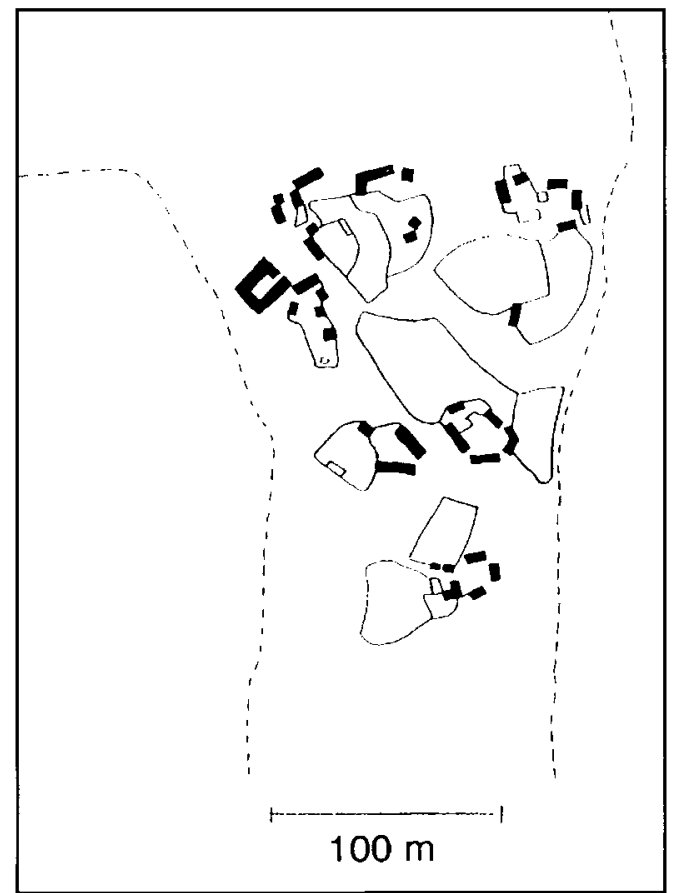

Fig. 7. The farms in the village of Kuamstad, Kalla parish, Öland. Drawn from a map from 1833.

es, since the medieval regulations of building lots had arisen from the specific historical situation of those villages (see Göransson $1980 ; 1985$ ).

It is therefore advisable to distinguish between settlements with a regular and concentrated structure and regulated settlements in their medieval context. During the Iron Age and in historical time there were also villages with an irregular and concentrated structure, like the example of Kvarnstad in the parish of Källa in Öland, fig. 7.

The causes for the very radical restructuring that actually occurred in Vorbasse in the beginning of the Iron Age, could perhaps instead be explained in the same way as Heiko Steuer explains the moving of villages and cemeteries in the Merovingian Provinces. He connects these changes to the rise of the earliest forms of enfeoffment, that is, parts of or entire villages coming under the supremacy of one or several landlords (Steuer 1989:112, 118). This is a very interesting idea which doubtlessly has relevance also for Scandinavian changes of settlements during these periods. However, it is probably more a matter of an enfeoffment of people, since the value of the land was related to its being cultivated by the peasants. Through the enfeoffment of people the land that they cultivated came also under the power and protection of the overlord (Gurevitj 1979:52ff).

The rise of regular patterns probably has many causes. When all the farms in a village have been simultaneously moved, this could lead to the rise of more regular structures. It must have been an excellent occasion to rationally plan the settlement with regard to new needs, new forms of ownership, etc. When this restructuring was repeated continuously, as has been shown for parts of Jutland, the possibilities for a more regulated formation increased.

In connection with very extensive colonization there were also great chances for regular patterns to occur, like in the example of Germanic expansion into eastern Europe during the twelfth and thirteenth centuries. Similar chances can be ascribed to areas devastated by war and conflagration (Göransson 1986: 37 , and literature therein quoted). A less extensive and more succesive colonization will instead result in single farms, which eventually develop into irregular, unregulated villages. A more regular and concentrated village structure can also have resulted from societal changes like the policy of kings concerning enfeoffments, and the process of feudalization as a whole (Dodgshon 1980:74), with villages coming under new lords (Steuer op. cit.), and with the introduction of permanent taxes (Porsmose 1981).

Swedish human geographers have instead pointed to the inherent potential for change in the agrarian society as being the determinant of changes in settlements (e.g. Göransson 1980:78; Sporrong 1985a:57).

My opinion is that the importance of technology, which together with other factors is often set in connection with the regulation and place continuity of the medieval villages (e.g. 
Porsmose 1981:30; 1982:26), is generally not a valid explanation for this restructuring or for changes in settlements as a whole. I will not go further into this matter, but concerning the place continuity I claim that the "laga läge" of the laws could have been decisive for the rise of what is usually called the stationary village. This kind of village is seen above all by Danish archaeologists and historians as a novelty and an opposite to the more or less continuously moving Danish villages of the Iron Age (Grøngaard-Jeppesen 1981; Porsmose 1981).

Unlike the attitude towards the creation of regular lots, the laws were much more restrictive concerning the removal of a village that was organized in "rätt skifte". In the provincial laws of Uppland and Västmanland it is stated that "ingen har rätt att riva upp en by som ligger i rätt solskifte, utan att alla jordägare samtycker" (no one has the right to break up a village that is placed in "rätt solskifte" without the consent of all the land-owners) (UL, B I; V mL, B I), and in the law of Östergötland it is stated that "ligger en by så, som den blev byggd enligt gammalt skick, och är detta lagligen stadfäst, då skall man jämka och icke riva upp" (if a village is situated as it was formed according to older ways acknowledged by the law, it should be adjusted, not broken up) (ÖgL, B I:6). The stipulations about the creation of the geometrical lots, the transition from "hammar-" or "fornt skifte" to "rätt skifte" or "laga läge" are on the contrary simple and were meant to promote regulation, which is evident in the laws of Västmanland and Uppland: 'Då tvingar en fjärdedel av byn en annan fjärdedel till skifte och halva byn den andra halva." (One quarter of them force another quarter to move, half of the village can force the other half.) (VmL, B I; UL, B I).

In this context it is important to note that, regarding the unregulated villages of northern Öland, it is often possible to trace on old maps the moves of separate farms within the village boundaries. This is sometimes also the case with the main part of the farms of a village. Majvor Östergren was able to show that the farms of Gotland from the middle of the Iron Age and through the entire Middle Ages often moved around within a given area (1989:117ff).

To summarize the discussion it can be stated that the Swedish villages or a greater part of them most likely were of an irregular shape before the Middle Ages, in conformity with the disjointed enclosed villages discussed above. This view has been confirmed by the archaeological source material of Öland and further strengthened by the historical source material. Other archaeological sources will be referred to below, and the view of single farms as being the sole existing form of settlement in the Iron Age will again be refuted with regard to other parts of Sweden than the above discussed.

\section{OTHER PARTS OF SWEDEN}

\section{Gotland:}

The fossil Iron Age settlements of Gotland have for the last decades been assumed to consist of single farms both by archaeologists and human geographers (e.g. Carlsson 1979; Östergren 1989). Earlier they had been classified as villages, "settlement areas", and single farms (Nihlén \& Boethius 1933), which in my opinion gave a more correct view.

Historical settlements have always been described in literature as solely consisting of single farms (e.g. Ersson 1974). This view has highly influenced the research concerning the old settlements of the island. However, in spite of it being easy to discern and distinguish single farms on Gotland, in contrast to Öland, there is no reason to deny the existence of villages during this period. That fossil settlements are often the remains of villages is quite clear to me. It is also remarkable that Vallhagar, which is the most studied block of house foundations or other large groupings of buildings in Gotland, has seldom or never been included in recent descriptions of Iron Age settlements.

Dan Carlsson divides the settlement in his area of examination into two groups: 
1.) single farms and 2.) separate farms that are linked to each other in a functional system. There are also a few groupings of two or three farms (1979:121). This classification of settlements is the most accepted among scholars today. However, both the second category and the groupings of two or three farms fulfil the quantitative and functional conditions ascribed to the application of the concept of "by". They should therefore be classified as "byar", villages! A classification of settlements into villages and single farms gives a more correct view of the fossil remains of Gotland. Still, single farms seem to have been reasonably common on the island and the majority of villages here were probably rather small, especially compared to the villages of Öland.

One exception is Vallhagar, which should be viewed as a rather large village. Mårten Stenberger estimated, from a number of criteria, the number of farms to be six or seven (1955:1147ff). Taking into account the destruction by cultivation which occurred in the western part of the island, and above all considering the number of house foundations, I claim that the number of farms must have been at least eight or nine. If this is correct Vallhagar could be an equivalent of the large Iron Age villages of Öland, which usually include 10-14 farms.

The similarities between Vallhagar and the Danish and Continental, more regularly formed, Iron Age villages have earlier been noted. In comparison with these Vallhagar is in fact a very large village. Several other Iron Age villages in Gotland have a similar form and similar characteristics, for example Visnar ängar in the parish of Alskog and Solängar in the parish of Sproge. These groupings and structures make the settlements of Gotland appear to have more in common with the Iron Age villages of Jutland than with the villages of Öland. Another apparent difference between the settlements of the two islands is that the farms of Gotland are usually placed on the border between infields and common (cf. Carlsson 1979), while the farms on Öland are most often centrally placed in the infields.

Later settlements of the Merovingian Age and the Viking Age have been interpreted by Majvor Östergren as solely consisting of single farms (1989:117ff). The clusters of farms that existed earlier, and the cooperation between them, were broken up and terminated during this period (Ibid.). The interpretation is based on her documentation of the repeated moves of the farms, and the fact that the farms during this period were more scattered than earlier (Ibid.) However, this does not necessarily imply that the community and cooperation that existed earlier had been terminated. The distance between the farms in a village can, as we have seen earlier, be very great, and differed widely in historical time.

At the end of the Viking Age and in the early Middle Ages, however, there was a tendency to form villages, the farms being more concentrated than earlier, a phenomenon which she describes as the "forming of a village with a disjointed enclosure system." (op. cit.: 219 ff). This description comes close to what has been said earlier about differences between historical unregulated villages and Iron Age villages in Öland. Following the definition of the concept of "by", this settlement should also be classified as consisting of "byar".

The historical settlements of Gotland have been viewed as consisting of single farms. The groupings of farms which in spite of this are found on the island, and those that exist in historical sources, have been said to be the results of the division of farmsteads during the Middle Ages or later and are therefore not treated as villages (Ersson 1974:219ff). This accepted interpretation is a clear example of including a genetic aspect in the concept of "by", which is thus based on the inaccurate opinion about how other, more "genuine" villages have come into existence. This has already been discussed earlier. In accordance with what was stated there, these historical groupings of farms should be treated as villages. Also, Majvor Östergren has convincingly shown that they did not necessarily result from the division of farmsteads. She 
has instead been able to show that the number of farms during the Viking Age and Middle Ages often correspond to the number of farms in historical times (1989:219).

There are thus no grounds for the point of view that denies the existence of villages in Gotland, neither regarding the Iron Age nor historical times. Also, in opposition to what is usually stated in the literature, there were, at least in the middle of the Iron Age, not only settlements of single farms and small villages but also large, regularly shaped villages.

\section{The Mainland:}

Concerning the southern provinces there was, as we have earlier seen, written evidence that villages existed in the pre-Christian period. With regard to Östergötland there is also a large archaeological source material in the form of a fossil agrarian landscape: systems of enclosure walls, crop marks and house foundation terraces, which can be used to illuminate conditions during the Iron Age. This material has mainly been used by human geographers.

Sven-Olof Lindquist, using his studies of Halleby as a starting point, interpreted these systems of enclosure walls as the remains of small villages with an average of three farms (1968:39f). Mats Widgren, on the contrary, meant that single farm settlements had been the sole existent settlement form in Östergötland during the Iron Age, and viewed the concentration of the settlement in Halleby as an exception. The separate farms were, according to Widgren, linked to each other in large fenced associations that included four or five farms in a village-like organisation (Widgren 1983:70; 1984:147). Widgren has later modified his view, now seeing the remains of settlements as comparable to villages of more recent periods, at least in the functional aspect (1986:20).

Since the fossil agrarian landscape of Östergötland lacks visible house foundations above ground, and few excavations have been undertaken, little is known about the appear- ance and contents of the settlements. The few house foundation terraces that have been registered can not be said to be representative of all the settlements. The studies of Halleby are the hitherto most extensive ones, and therefore it is not correct to view the concentration of buildings of that settlement as an exception.

As was earlier touched upon, the fossil systems of enclosure walls are very similar to those in Öland. Above all this concerns the shape of enclosures and the number of cattle roads, and also probably the placing of the farms in the areas of infields. Since the areas occupied by systems of enclosure walls are often of a similar size to the villages in Öland, it is also very probable that the number of farms in the two areas have corresponded. The registered systems at Särstad in the parish of Rinna (see Widgren 1986:22, fig. 1) are in their entire structure a complete parallel to the enclosed areas of a large Iron Age village in Öland and must be viewed as a village of corresponding size.

Also in the western parts of Östergötland, which are otherwise characterized by very regularly shaped villages in historical times, there are examples of unregulated villages with scattered buildings (Helmfrid 1962:168).

\section{The provinces surrounding Lake Mälaren:}

When interpreting the Iron Age settlement of the provinces surrounding Lake Mälaren as consisting of single farms, the main source material has been graves. This interpretation can no longer be said to be true, since more recent studies have shown that the smaller cemeteries are not more common than large cemeteries in this region. On the contrary, most cemeteries can be viewed as village cemeteries. However, a disproportionate share of the small cemeteries has been excavated (Bennett 1988:145ff). The opinion about the size of the cemeteries being related to how long they were in use, is also incorrect. Cemeteries of similar size have been shown to 
have been in use between three and six centuries, representing settlements of between two and four farms (ibid.).

Accordingly there are no longer any grounds for the belief that Iron Age settlement structure in these areas was one of single farms only. Early as well as recent thorough examinations of cemeteries in this region have also clearly pointed to village populations. (Baudou 1965:60; Johnsen-Welinder \& Welinder 1973; Petré 1984:153; 1988:247).

\section{AGRICULTURE AND STOCK-RAISING}

Human geographers earlier explained the appearance of villages with reference to agricultural changes, a view which presupposed the dominant position of agriculture in the economy, and also presupposed that changes of agriculture automatically led to changes in settlement. Recent studies and interpretations of the introduction of the two-field system show that the change was less drastic than earlier thought (Carlsson 1986b), a fact that lessens its explanatory value concerning changes in settlement. Also, the formation of the geometrically regular villages in Öland can not be said to be related to any regular system of fallow, since the single-field system was dominant until the eighteenth century (Göransson 1985:7lf). At present the economic role of agriculture during the Iron Age is not seen as important, but it is common to stress its symbolic importance and its importance for forms of ownership (Sporrong 1985a:193).

It can of course be called into question whether agriculture ever had a dominant position in Iron Age economy, and archaeological sources contradict it. This was also stated by archaeologists (Hyenstrand 1974:32), but at the same time the fact that stock-raising dominated the economy, and not agriculture, was used as an argument for the hypothesis that villages did not exist during the Iron Age (Ibid.). However, this argument denies the influence of cattle raising on the shaping of villages, and at the same time it claims that agriculture is a condition for the formation of villages, which can be shown to be incorrect. The calculations of the size of arable land in the Iron Age, taking as a starting point remaining fields and systems of enclosure walls, have shown that the fields were generally very small (Carlsson 1979:119; Fallgren 1988:38f; Widgren 1983:72).

The fact that the economic role of stockraising was important is, however, totally clear. This is confirmed in many ways by the archaeological source material: firstly, the number of cribs in excavated Iron Age houses was large (Myrdal 1984:86). It can also be proved that stock-raising had a considerable influence on Iron Age planning and structuring of settlements (Fallgren 1988:61ff; Widgren $1984: 116 ; 1986: 22 f)$. This is also true concerning historical villages. Enclosures and cattle roads, and often the placing of the buildings, have been made according to the needs of cattle-raising (Erixon 1960:225ff). Even where an open-field system was applied, it was a method of letting all parties rationally use the pasture after harvesting and on fallow ground.

The occurrence and design of the enclosure wall systems in Öland were functionally a result mainly of an intensive form of cattleraising (Fallgren 1988: op. cit.), in addition to factors of cultivation and dispositions earlier discussed.

The most important thing to point out in this context is that economic conditions have not been of any importance in the forming of villages. However, the type of economy involved has often influenced the appearance of the villages. There were villages already during the Stone Age. Furthermore, man is biologically a social animal (Ghiglieri 1989). In this context it is interesting to note that large irregular villages, whose populations mainly supported themselves by hunting and fishing, still existed in eastern Finland during the late Middle Ages (Saarenheimo 1981, KLNM 10:223). 


\section{MULTICENTERED SETTLEMENTS}

The human geographers' characterization of Iron Age settlements as having more than one centre, which later was accepted by archaeologists, is, as mentioned earlier, deeply rooted in the sources. It has clearly been confirmed by studies of maps of Mälardalen (Sporrong 1985a:115, 191) and is touched upon in archaeological studies (Broberg 1990;24f, and other literature therein quoted). However, the interpretation of this phase as being dominated by single farms is, as shown above, quite incorrect. The existence of more than one centre is of course characteristic of all the fossil remains of settlements treated alone: settlements of Öland, Gotland and Östergötland which have been shown to have been mainly village settlements. Also, the division of farmsteads into several groups of farms was typical of the unregulated historical villages in Sweden. Before the regulation of lots the farms were often scattered over the area of infields.

The existence of more than one centre, which can be traced through studies of old maps or which is shown by archaeological investigation, is a remnant of past groupings of the villages. In the provincial law this fact was also more or less evident in the paragraphs concerning the regulation of lots. In Mälardalen there are also several areas with fossil systems of enclosure walls and house foundation terraces, similar to, for example, the ones in Östergötland. There had also existed unregulated villages in this region, e.g. Gamla Uppsala by (Ramqvist 1986:254), and the villages of the region have in many cases been regulated during the seventeenth and eighteenth centuries (Göransson 1980:82; 1985:75f).

This case can also prove valid for Skåne, where it has been revealed that the number of Merovingian and Viking settlements are often twice that of the historic villages of the area. The settlements are assumed to have consisted of small, middle-sized or large groups before the occurrence of the medieval villages
(Callmer 1986:167ff; Stjernquist 1981:17ff). The large number of earlier settlements in the villages can thus, in accordance with what is stated above, be interpreted as the remains of scattered farms or groups of farms that existed before the medieval regulations changed the structure of the villages. The existence of Iron Age villages in the area has been confirmed by the studies in Fosie (Björhem \& Säfvestad 1982:154).

Also in the southern part of Norrland, where house foundation terraces are the only visible signs of Iron Age settlements, there are indications of similar conditions. In Hälsingland, where most terraces have been found, the settlements have also been viewed as single farms (Liedgren 1984:94). The distance between separate terraces/farms has been decisive for the interpretation (Ibid.). Since there are no fossil systems of enclosure walls in these areas it is of course difficult to link the farms to each other. However, as we have seen, the distance between the farmsteads in a village can be considerable. Furthermore, it is not possible to state that the terraces correspond to the entire original settlement area, see below. The densest concentration of house foundation terraces in Hälsingland is situated near Lake Bäling (see Liedgren op. cit.: fig 19) where 10 farms have been registered. From what has been said about the fossil villages of Öland this area probably contains the remains of a village. Several of the villages in Hälsingland had very scattered buildings in historical times (Erixon 1960:249).

\section{ABOUT THE PROBLEMS OF REPRESENTATION AND SOURCES CONCERNING SETTLEMENT ARCHAEOLOGY}

It is very likely, in my opinion, that the settlements of the Swedish mainland had a similar structure of Iron Age villages as on Öland. This is indicated, among other things, by the fossil systems of enclosure walls in Östergötland and the provinces around Mälaren, and 
also by the spatial distribution of house foundation terraces in Hälsingland. It is also confirmed by the existence of more than one centre that can be proved to have preceded the regulated villages, and furthermore by the references in the provincial laws to the earlier structures of villages. The spread of the unregulated villages in historical times, from Blekinge in the south to Norrbotten in the north, further support this hypothesis (see Erixon 1960).

The main reasons that so few Iron Age villages have been found through archaeological investigations on the mainland is, in my opinion, precisely the scattered structure that was probably typical of these villages. In spite of the large excavations motivated by land development in recent years, it is (unlike in Jutland, Denmark) very difficult to archaeologically distinguish and define these villages, the distance between the northernmost and southernmost farmstead in the same village being a kilometer or more, and the distance between each farm 100-200 meters or more.

Another problem of archaeological sources are the house foundation terraces, particularly when they are the sole visible remains of a settlement, as they are in the fossil enclosure walls systems of Östergötland, Mälardalen, Hälsingland and other parts of southern Norrland. It has often been assumed that these registered remains formed the entire or main part of the settlements of a larger area. It has also been common to compare house foundation terraces to a certain phase of the Iron Age. But terraces are only arranged when a house is built on a slope. No other possible buildings can be discovered before an archaeological excavation has taken place.

The villages of Öland which were treated earlier are excellent and illuminating examples of this phenomenon. In Rosendal, where 14 house foundations were built, two of them were built on terraces, linked to each other by a third. If there had been no stone fences, or if the walls of the houses had not been built of stone, only two houses of fourteen would have been discovered. The conditions in
Skäftekärr are similar: only one of the buildings in the central farmstead was built on a terrace.

Thus house foundation terraces tell only about a limited sphere of a farm or village. Terraces should therefore not be allowed to represent a given settlement, neither in a local perspective nor in a regional or even larger perspective.

\section{A SHORT NOTE ON THE SETTLEMENTS AND AGRARIAN LANDSCAPE IN THE LATE IRON AGE}

One of the reasons that settlement archaeologists have difficulty in linking Iron Age settlements to historical settlements, is that all the above-described fossil enclosure wall systems are generally assigned to the early Iron Age (Carlsson 1979; 1986a:29f; Sporrong 1985a:193; Widgren 1983:116f). The agrarian landscape of the late Iron Age is therefore considered to be unknown, a phenomenom normally explained by a transition to building fences of wood (Ibid.). No matter how one views using $\mathrm{Cl}$ 14-datings on stone fences, there are also C14-datings which assign stone fences to the late Iron Age or even later periods (see Sporrong op. cit.:163). There is no reason whatsoever to believe that stone fences were not used or built after the early Iron Age, or that wood fences were not used during the Iron Age. In those places in Rosendal, fig. 1, where the stone fences end abruptly, it cannot be explained by destruction by cultivation or other later destruction, rather that these enclosures must have continued in the form of wooden fences. This phenomenom can still be studied today in the villages of northern Öland, where different building materials succeed each other in one enclosure, just as they did during older periods. Linné's description of eighteenth century enclosures on southern Öland shows several variations and combinations in building materials and methods: stone walls, bushes and sprigs were used (Linné 
1741:54). That the use of wood or stone in enclosure walls is related to a specific period is thus quite incorrect.

As we have seen, there are no considerable structural or morphological differences between villages of the early Iron Age and the unregulated seventeenth century villages of northern Öland. Thus, the villages and the agrarian landscape in Öland could not have been very different during the Viking Age or the early medieval period, even though we do not know how the farms actually looked during this period.

\section{CONCLUSION.}

The village in itself has probably always existed. The structures of villages have however varied considerably, depending on many factors such as local conditions and historical situations. Village settlements have in my opinion been the normal form of settlement during the Iron Age. Naturally there were also single farms during the periods discussed, and they were common in some parts of the country at least during brief periods. However, even if the number of single farms in a given area exceeded the number of villages in the same area for a shorter or longer period of time, it is my conviction that the majority of the people in this area lived as neighbours in a village.
Irregular villages with scattered farms, the fields being separate and enclosed, seem from what has been stated here to have been common in this country during the Iron Age. However, it is also possible that more regular and concentrated villages existed in some parts of the country. When, and if, the villages were regulated during the Middle Ages or later, farms were moved to a common geometrically formed lot, where the fields were mixed in an open common area of infields. This structure and inner organisation was kept until the enclosure movement of the eightteenth and nineteenth centuries, when the common collective of the village was finally dissolved. Where this dissolution was consequently carried through, the landed property was spatially distributed in a way that strongly reminds us of Iron Age conditions!

Translated by Ylva Hasselberg. English revised by Laura Wrang.
ABBREVATIONS
$\mathrm{UL}=$ Upplandslagen
$\mathrm{VmL}=$ Västmannalagen
$\mathrm{VgL}=$ Västgötalagen
ÖgL = Östgötalagen
$\mathrm{B}=$ Byggningabalken/Byalagsbalken
KLNM = Kulturhistoriskt Lexikon för Nord- isk Medeltid. 
Ambrosiani, B. 1964. Fomlämningar och bebyggelse. Stockholm.

Baudou, E. 1965. Gävletrakten under vikingatiden. Undersökningar på gravfälet vid Järvsta. Gävle.

Becker, C. J. 1982. Enkeltgård og landsby i Danmarks äldre jernalder. Gärdens udvikling fra jemalder til nyere tid. Udg. af Henrik Thrane og Torben Gröngaard-Jeppesen.

Bennett, A. 1987. Mälarområdets järnåldersgravfält. 7000 år på 20 àr. Arkeologiska undersökningar $i$ Mellansverige. Slockholm.

Björhem, N \& Säfvestad, U. 1982. Fosie IV: Bebyggelsemönster i långtidsperspektiv. Gårdens udvikling frajernaldertil nyere tid. Udg. af Henrik Thrane og Torben Gröngaard-Jeppesen.

Broberg, A. 1990. Bönder och samhälle i statsbildningstid. En bebyggelse arkeologisk studie av agrarsamhället i Norra Roden 700-1350. Rapporter frăn Barknåre-projektet III. Upplands formminnesförenings tidskrift 52. Uppsala.

Callmer, J. 1986. To stay or to move. Some aspects of the settlements dynamics in Southern Scandinavia in the seventh to twelvth centuries A. D. with special reference to the province of Scania, Southern Sweden. Medd. frän Lands universitets historiska museum 1985-1986. Lund.

Carlsson, D. 1979. Kulturlandskapets utveckling pa Gotland. Medd. B 49. Kulturgeogr. inst., Stockholms universitet.

- 1986 a. Kontinuitet och förändring. Gotlandsgården under förhistorisk tid och medeltid. Ymer.

- 1986 b. The Ancient Cultivation of Arable Land. Striae, Vol. 24. Uppsala.

Dahlbäck, G. 1977. Arkeologisk och kulturgeografisk bebyggelschistorisk lorskning i Sverige. Historisk tidskrift for Finland 62.

Dodgshon, R. 1980. The origin of British field systems. London, New York, Toronto, San Franscisco.

Edgren, B \& Herschend, F. 1982. Arkeologisk ekonomi och ekonomisk arkeologi. Ett försök till beskrivning av de öländska jordbrukets förutsättningar under äldre järnålder. Fornvämmen.

Erixon, S. 1952. Uppslagsordet "by". Svensk uppslagsbok, 2:a upplagan. Malmö.

- 1960. Sienska byar utan systematisk reglering I-II. Stockholm.

Ersson, P-G. 1974. Kolonisation och ödeläggelse på Gotland. Studier av den agrara bebyggelseatvecklingen frän tidig medeltid till 1600-talet. Medd. frăn Kulturgcografiska inst., nr B 27. Stockholms universitet.

Fallgren, J-H. 1988. Bebyggelsestrukturer och markanvändning på Öland under jämàldern. C-uppsats, Arkeologiska inst.. Uppsala universitet.
Fischer Drew, K. 1991. The Laws of the Salian Franks. Translated and with an introduction by Katherine Fischer Drew. Pennsylvania.

Ghiglieri, M. P. 1989. Hominoid sociobiology and hominid social evolution. Understanding chimpanzees. Ed: Paul G. Heltne, Linda A. Marquardt. Harvard Univ.

Gröngaard-Jeppesen, T. 1981. Middelalderlandsbyens opstäen. Fynske studier XI. Odense.

Gurevitj, A. 1979. Feodalismens uppkomsti Västeuropa. Borås.

Göransson, S. 1969. Morphogenetic Aspects of the Agrarian Landscape of Öland. Oikos supplementum 12. Köpenhamn.

- 1980. Regular Settlements in Scandinavia: the Metrological Approach. Landscape History 1979:1.

- 1985. De regelbundna strukturerna i Östsveriges bebyggelsegeografi. Ett försök till preciseringar av utbredning och kronologi. Särtryck ur Kulturgeografiskt perspektiv.Geografiska regionstudier $m / 5$. Uppsala.

- 1986. Om svenska byar med regelbunden form. Historisk geografi. Ymer '86. Helsingborg.

Hannerberg, D. 1977. Kumlabygden $N$, By, gärd och samhäle. Kumla.

Hatt, G. 1939. The ownership of cultivated land. Det Kgl. Danske Videnskabers Selskab. Historisk filologiske meddelelser. XXVI, 6.

Helmfrid, S. 1962. Östergötland "Västanstäng". Studien iiber die altere Agrarlandschaft whd ihe Genese. GA XLIV.

Hvass, S. 1988. Jernalderens bebyggelse. Jernalderens stammesamfand. Fra Stamme til Stat i Danmark I. Århus.

Hyenstrand, A. 1974. Centralbygd-Randbygd. Actal Universitatis Stockholmiensis, Studies in NorthEuropean Archaeology 5.

Johnsen-Welinder, B. \& Welinder, S. 1973. Jämåldersgravfäl i Mälardalen. Acta Arch. Lundensia. No 2. Lund.

Liedgren. L. 1984. Iron Age Settlements in Hälsingland, Northern Sweden. Evert Baudou (ed.) Papers in Northern Archaeology. Archaeology and Environment 2. Umeå.

Lindquist, S-O. 1968. Det förhistoriska kulturlandskaper iöstra Östergötland. Hallebyundersökningen I. Acta Universitatis Stockholmiensis, Studies in NorthEuropean Archaeology 2.

Lindqvist, S. 1935. Svenskarna i heden tid. Stockholm. Linné. C. von. 1741. Öländska och gotländska resa. Redigerad av Carl-Otto von Sydow 1977. London.

Myhre, B. 1983. Beregning av folketall på Jären i yngre romertid og folkevandringstid. Hus, gaird och bebyggelse. Reykjavik.

Myrdal. J. 1984. Elisenhof och järnålderns boskapssköısel i Nordvästeuropa. Formä̈nnen. 
Nihlén. J \& Boëthius, G. 1933. Goländska gårdar och byar under jämålder. Stockholm.

Petré, B. 1984. Arkeologiska undersökningar på Lovö. Del 4. Acta Universitatis Stockholmiensis. Studies in North-European Archaeology 10. Stockholms universitet.

- 1988. A three decade archaeological project-the Lovö project. BAR Intemational Series $366(\mathrm{ii})$. Oxford.

Porsmose, E. 1981. Den regulerade landsby. Studier over bebyggelseutviklingen på Fyn i tiden fra ca 1700 ill ca lo00 e Kr födsel 1-11. Viborg.

- 1983. Middelalderlandsbyen. Produktionsstruktur og utbytningsstruktur. $K S / / 83$. Kulturgeografiska inst. Stockholms universitet.

Ramqvist, S. 1986. Gamla Uppsala by. Upplands största. Från Östra Aros till Uppsala. En samling uppsatser kring det medeltida Uppsala. Uppsala stads historia VII. Uppsala.

Salarenheimo, J. 1981. KLNM 10:223.

Schmid, P. 1986. Siedlungsstrukturen. Archäologische und natarwissenschaftliche untersuchangen an ländlichen und frühstädtischen siedlungen $\mathrm{im}$ deutschen küstengebiet vom 5. jahrhundert v. Chr. bis zum /l. jahrhundert n. Chr. Band / Ländliche siedlungen. Herausgegeben von G. Kossack, K-E Behre und P. Schmid.

Sporrong. U. 1971. Kolonisation, bebyggelseutveckling och administration. Medd. B 23, Kulturgeografiska inst., Stockholms universitet.

- 1985 a. Malarbygd. Agrar bebyggelse och odling ar ett historisk geografiskt perspektiv. Medd. serie B 61. Kulturgeografiska inst., Stockholms universitet.

- 1985 b. Uppslagsordet "by". Medeltidens ABC. Statens historiska museum.

Sporrong. U.\& Widgren, M. 1986. Ägande och disposition av mark som förklaringsfaktorertill kulutalandskapets wreckling. Mimeo. Dept. Human Geogr, Univ Stockholm.

Stenberger, M. 1933. Öland under äldre järnalder. KVHAA Monografier. Stockholm.

- 1955. The Finds and the Dating of the Vallhagar Settlement. Vallhagar II. Köpenhamn.
Steuer, H. 1989. Archaeology and History: Proposals to the Social Structure of the Merovingian Kingdom. The Birth of Europe: Archaeology and Social Developement in the First Millenium A. D. Ed: K Randsborg. Roma.

Stjernquist, B. 1981. Arkeologisk forskning om den agrara bebyggelsen $\mathrm{i}$ Skåne vid vikingatidens slut källäge och problemställningar. Bebyggelsehistorisk tidskrift $n r 2$. Stockholm.

Söderberg, S. \& Brate, E. 1906. Ölands runinskrifter. Stockholm.

Tacitus, Cornelius. Germania I. Udgivet af N. W. Bruun og A. A. Lund. Århus 1974.

Upplandslagen(UL). Suenska landskapslagar. Första serien. Utg. av $\AA$. Holmbaick och E. Wessén. Uppsala 1933.

Widgren, M. 1983. Settlement and farming systems in the early Iron Age. Stockholm.

- 1984. Bebyggelse och kulturlandskap i Östergöıland under järnåldern. L. Liedgren \& M. Widgren(red). Gård och kulturlandskap under jänaildern. KGS 2/ 84. Stockholms universitet.

- 1986. Fossilt odlingslandskap i fornlämningsregistret. Bebyggelsehistorisk tidskrift /1. Stockholm.

- 1992. Bysamfälighet och legskifie i Bohusläns byar. Opubl. manus.

Västgötalagen(VgL I \& II). Svenska landskapslagar. Femte serien. Utg. av Å. Holmbäck och E. Wessén. Uppsala 1946.

Västmannalagen(VmL). Svenskalandskapslagar. Andra serien. Utg. av $\AA$. Holmbäck och E. Wessén. Uppsala 1936

Östergren, M. 1989. Mellan stengrund och stenhus. Gotlands vikingatida silverskatter som boplatsindikation. Theses and Papers in Archaeology. 2. Stockholm.

Östgötalagen(ÖgL). Svenska landskapslagar. Första serien. Utg. av $\AA$. Holmbäck och E. Wessén. Uppsala 1933.

I want to thank Mats Widgren. who let me borrow his unpublished manuscript. 